\title{
Comparison of color discrimination in chronic heavy smokers
}

\section{and healthy subjects [version 1; peer review: 1 approved with}

\section{reservations, 1 not approved]}

\author{
Thiago Monteiro de Paiva Fernandes¹, Natanael Antonio dos Santos (iD) 1,2 \\ 1Department of Psychology, Federal University of Paraiba, Joao Pessoa, Brazil \\ ${ }^{2}$ Perception, Neuroscience and Behavior Laboratory, Federal University of Paraíba, Joao Pessoa, Brazil
}

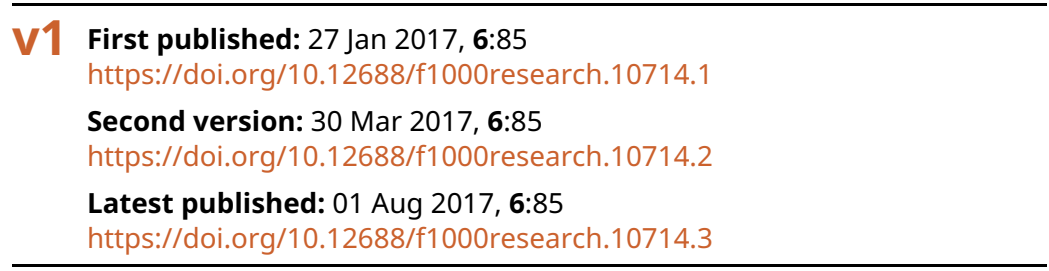

\section{Abstract}

Background: Cigarette smoke is probably the most significant source of exposure to toxic chemicals for humans, involving health-damaging components, such as nicotine, hydrogen cyanide and formaldehyde. The aim of the present study was to assess the influence of chronic heavy smoking on color discrimination (CD). Methods: All subjects were free of any neuropsychiatric disorder, identifiable ocular disease and had normal acuity. No abnormalities were detected in the fundoscopic examination and in the optical coherence tomography exam. We assessed color vision for healthy heavy smokers $(n=15$; age range, 20-45 years), deprived smokers ( $n=15$, age range 20-45 years) and healthy non-smokers ( $n=15$; age range, 20-45 years), using the psychophysical forced-choice method. All groups were matched for gender and education level. In this paradigm, the volunteers had to choose the pseudoisochromatic stimulus containing a test frequency at four directions (e.g., up, down, right and left) in the subtest of Cambridge Colour Test (CCT): Trivector. Results: Performance on CCT differed between groups, and the observed pattern was that smokers had lower discrimination compared to non-smokers. In addition, deprived smokers presented lower discrimination to smokers and non-smokers. Contrary to expectation, the largest differences were observed for medium and long wavelengths. Conclusions: These results suggests that cigarette smoke and chronic exposure to nicotine, or withdrawal from nicotine, affects $C D$. This highlights the importance of understanding the diffuse effects of nicotine either attentional bias on color vision.

\section{Keywords}

cigarette smoking, visual system, color discrimination, color vision, Cambridge Colour Test, Trivector, nicotinic receptor

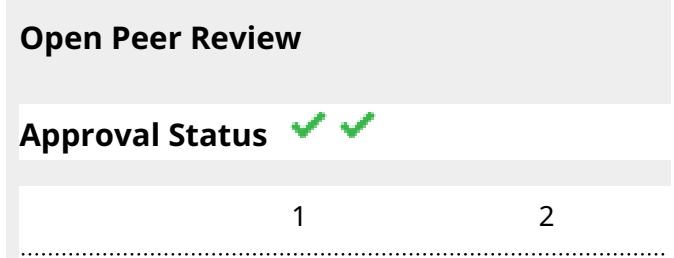

version 3

(revision)

01 Aug 2017

version 2

(revision)

30 Mar 2017

version 1

27 Jan 2017
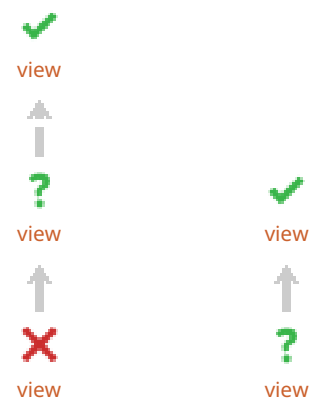

1. Goro Maehara, Kanagawa University,

Yokohama, Japan

2. Marine Raquel Diniz da Rosa, Federal

University of Paraíba , João Pessoa, Brazil

Any reports and responses or comments on the article can be found at the end of the article. 
This article is included in the Eye Health

gateway.

Corresponding author: Thiago Monteiro de Paiva Fernandes (thiagompfernandes@gmail.com)

Competing interests: No competing interests were disclosed.

Grant information: National Counsel of Technological and Scientific Development (CNPq), Brazil (grant no., 303822/2010-4), CAPES and Federal University of Paraiba funded this paper

The funders had no role in study design, data collection and analysis, decision to publish, or preparation of the manuscript.

Copyright: @ 2017 Fernandes TMdP and dos Santos NA. This is an open access article distributed under the terms of the Creative Commons Attribution License, which permits unrestricted use, distribution, and reproduction in any medium, provided the original work is properly cited. Data associated with the article are available under the terms of the Creative Commons Zero "No rights reserved" data waiver (CCO 1.0 Public domain dedication).

How to cite this article: Fernandes TMdP and dos Santos NA. Comparison of color discrimination in chronic heavy smokers and healthy subjects [version 1; peer review: 1 approved with reservations, 1 not approved] F1000Research 2017, 6:85 https://doi.org/10.12688/f1000research.10714.1

First published: 27 Jan 2017, 6:85 https://doi.org/10.12688/f1000research.10714.1 


\section{Introduction}

Cigarette smoking is still a major source of exposure to chemicals that are toxic for humans. The compounds in cigarettes and cigarette smoke, such as nicotine, oxygen dioxide and formaldehyde, are highly harmful to health ${ }^{1}$. Data from the World Health Organization (WHO) hypothesize that by 2030 , cigarettes could kill nearly 9 million people a year around the world ${ }^{2,3}$.

Cigarette nicotine deprivation in chronic users may impair cognitive and attentional abilities even after long time of cessation ${ }^{4,5}$. The neurotoxic effects of chronic use and smoking abstinence on the nervous system have not been extensively studied ${ }^{6-8}$. The need for establishing reliable measures that assess the effects of smoking on sensory, perceptual and cognitive domains is crucial to fill these gaps.

A visual percept may consist of stimuli that vary over the space (spatial contrast), time (temporal contrast) or direction of motion, and vary in luminance (achromatic) and chromaticity (saturation and hue color $)^{9-11}$. Thus, chromatic contrast involves chromaticity differences, which can be expressed by the distance in the CIE 1976 uniform chromaticity scale diagram and assessed by the size of MacAdam ellipses on the Cambridge Color Test (CCT), for example 12,13 .

We base our rationale on the premise that chronic exposure to nicotine will led to receptor desensitization and not suffer influence of arousal and increase in attentional resources in smokers ${ }^{14}$. The purpose of the present study was to assess the influence of chronic heavy smoking on color discrimination (CD).

\section{Methods}

Participants

In this study, 15 non-smokers (mean age $=32.5$ years; $S D=9.1$; 7 male), 15 cigarette smokers (mean age $=32.1$ years; $S D=5.7$; 7 male) and 15 deprived smokers (mean age $=31.9$ years; $S D=6.3$; 7 male) between the ages of 20 and 45 years, who were working as staff or were students at Federal University of Paraiba, were recruited through printed advertisements. Participants were excluded if they had any one of the following criteria: younger than 20 and older than 45 years (since the effects of the human visual system immaturation or aging could superestimate the results ${ }^{15,16}$ ); current history of neuropsychiatric disorder; a history of head trauma, color blindness, current or previous drug abuse; drinking more than 10 alcoholic drinks per week or current use of medications that may affect visual processing and cognition. In addition, subjects were required to have a good ocular health: no abnormalities were detected in the fundoscopic examination and in the optical coherence tomography (OCT) exam. All participants had normal or corrected-to-normal vision as determined by a visual acuity of at least 20/20.

Smokers reported a smoking history of at least 8 years, currently smoked more than 20 cigarettes/day and had a score of $>5$ on the Fagerstrom Test for Nicotine Dependence (FTND) ${ }^{17}$. Deprived smokers were asked to smoke only after the experiment $(\approx 6 / 7$ hours of deprivation). Smokers and deprived smokers began smoking at an average of 16.5 years of age $(S D=3.25)$ and had been smoking for an average 15 years $(S D=6.45)$. Non-smokers had never smoked a cigarette. Smokers were allowed to smoke until the beginning of experiment.

This research followed the ethical principles from the Declaration of Helsinki and was approved by the Committee of Ethics in Research of the Health Sciences Center of Federal University da Paraiba (CAAE: 60944816.3.0000.5188). Written informed consent was obtained from all participants.

\section{Color discrimination test}

Stimuli were presented on a 19 inch LG CRT monitor with $1024 \times 786$ resolution and a rate of $100 \mathrm{~Hz}$. Stimuli were generated using a VSG 2/5 video card (Cambridge Research Systems), which was run on a microcomputer Precision T3500 with W3530 graphics card. All procedures were performed in a room at $26 \pm 1^{\circ} \mathrm{C}$, with the walls covered in grey for better control of luminance during the experiments. All measurements were performed with binocular vision. Monitor luminance and chromatic calibrations were performed with a ColorCAL MKII photometer (Cambridge Research Systems).

The color vision test was performed using CCT, version 2.0, with Trivector subtest (Cambridge Research Systems; http://www.crsltd. com/tools-for-vision-science/measuring-visual-functions/cambridge-colour-test/). The CTT was performed in a darkened room with illumination provided only by the monitor used to present visual stimuli. Trivector provides a clinical assessment of color vision deficiencies as a rapid means screening of the existence of congenital or acquired deficits ${ }^{12}$. CCT uses pseudoisochromatic stimuli (Landolt C) defined by the test colors that are to be discriminated, on an achromatic background. The figure and the background are composed of grouped circles randomly varying in diameter and having no spatial structure (variation of $5.7^{\circ}$ arcmin of external diameter and $2.8^{\circ}$ arcmin of internal diameter). The luminance variation in each response avoids the existence of learning effect or use of tricks to respond correctly.

The four-alternative forced-choice ${ }^{12,18}$ (4-AFC) method was used, and the subjects' task was to identify, using a remote control response box, whether the Landolt ' $\mathrm{C}$ ' stimulus was presented at the left, right, up or down side of the monitor screen. The participant was instructed to answer even if could not identify the stimulus gap ${ }^{12}$. After each correct answer, the chromaticity of the target proceeded closer to that of background, while each wrong answer or omission was followed by the presentation of the target at a greater chromatic distance from the background. The step on the staircase was doubled or divided by two after each incorrect or correct answer, respectively. This process took place throughout the experiment. The experiment ended after 11 reversals for each axis and the threshold was estimated from the six final reversals ${ }^{19}$.

The trivector testing protocol estimates sensitivity for the short, medium and long wavelengths through the protanopic, deuteranopic, and tritanopic confusion axes, respectively ${ }^{19,20}$. Trivector protocol uses vectors as central measurement. The advantage of this brief test is that it can be performed in about 5 minutes and provides a reliable result. ${ }^{12}$ The three confusion axes converge at 
a point called 'point of intersection', and the xy coordinates used were: protan $(0.6579,0.5013)$, deutan $(-1.2174,0.7826)$ and tritan $(0.2573,0.0000)$ (for more details, see 13$)$.

In general, we used a default setting where the Landolt ' $\mathrm{C}$ ' had an opening at $1^{\circ}$ of visual angle, minimum luminance of $8 \mathrm{~cd} / \mathrm{m}^{2}$, maximum luminance of $18 \mathrm{~cd} / \mathrm{m}^{2}, 6 \mathrm{~s}$ of response time for each trial and distance of $269 \mathrm{~cm}$ between participant and monitor screen.

Most of these procedures were performed late in the morning or mid-afternoon. Here we used Weber contrast ${ }^{21}$ :

$C=\frac{L_{\text {Max }}-L_{\text {Min }}}{L_{\text {Background }}}$

where $\mathrm{C}$ is the contrast value, $L_{\max }, L_{\min }$ and $\mathrm{L}_{\text {Background }}$ are luminance maximum and minimum and luminance of the background, respectively.

\section{Data analysis}

The distributions for each group were compared with Shapiro-Wilk. Both groups showed non-normal distribution, thus non-parametric statistical methods were used to analyze the data. For group comparisons, the non-parametric univariate analysis was used, with pairwise comparisons by Mann-Whitney $U$ test. Spearman's rank correlation coefficients (rho) were conducted to assess the relationship between outcomes of color discrimination data and biosociodemographic variables, such as age, gender and education level. All the calculations were made using SPSS ${ }^{\circledR}$, version 21.0.

The effect size $(r)$ estimation was used from the conversion of Z-score ${ }^{22,23}$ :

$r=\frac{z}{\sqrt{N}}$

Results are presented as medians. Center lines show the medians; box limits indicate the 25 th and 75 th percentiles as determined by SPSS software; whiskers extend 1.5 times the interquartile range from the 25th and 75th percentiles (ends of the whiskers are the maximum and minimum values). When presented, errors bars represent standard deviations (SD) of the median based on 1000 bootstrap resamplings. Bonferroni correction was the method of adjusting the $P$-value that we used. $P<0.016$ was accepted as statistically significant for multiple comparisons and $P<0.025$ for pairwise comparisons.

\section{Results}

There were significant differences in discrimination thresholds between groups along the protan $\left(\chi^{2}(2)=26.53, P<0.001\right)$, deutan $\left(\chi^{2}(2)=22.40, P<0.001\right)$ and $\operatorname{tritan}\left(\chi^{2}(2)=14.93, P<0.001\right)$ axes. The results of the trivector measurements are shown in Figure 1.

Along protan vectors (Figure 1A), pairwise comparisons showed significant differences between non-smokers vs. smokers $(U=132$,
$P=0.002, r=-.61)$, non-smokers vs. deprived smokers $(U=105$, $P<0.001, r=-.85)$ and smokers vs. deprived smokers $(U=136$, $P=0.002, r=-.58)$.

Along deutan vectors (Figure 1B), pairwise comparisons showed significant differences between non-smokers vs. smokers $(U=136$, $P=0.001, r=-.58)$, non-smokers vs. deprived smokers $(U=108$, $P<0.001, r=-.83)$, and smokers vs. deprived smokers $(U=154$, $P=0.024, r=-.43)$.

Along tritan vectors (Figure 1C), pairwise comparisons showed significant differences between non-smokers vs smokers $(U=$ 140, $P=0.003, r=-.55)$ and non-smokers vs. deprived smokers ( $U=126, P<0.001, r=-.67)$. There was no statistically significant differences among smokers vs. deprived smokers $(P=0.250)$.

\section{Correlations}

There is no relationship between color discrimination and gender (chi-square $=72, \mathrm{df}=39, P>0.05$ ). A spearman correlation showed no correlation between FTND and trivector data $(P>0.050)$, color discrimination and education years [rho $=.078, P=0.515]$, and color discrimination and age [rho $=.096, P=0.347]$.

\section{Dataset 1. Patient demographics and Trivector results}

http://dx.doi.org/10.5256/f1000research.10714.d150059

Raw data of the subjects biosociodemographic and trivector (protan, deutan and tritan) results.

\section{Discussion}

The data indicated that smoker groups, as a whole, had less discrimination when compared to non-smokers $(P<0.05)$, indicating the existence of a diffuse impairment in visual processing.

Small differences in blue-yellow color processing suggest that sensor neurons responsive to the short wavelength may differently operate from those responding to medium and long wavelengths. Indeed, the koniocelular pathway may not suffer from the influences of tobacco components.

Along the trivector protocol, smokers were more sensitive to protanopic and deuteranopic confusion axes (Figure 1). An effect size analysis confirmed that smokers had the largest discrimination errors for protanopic $(r=-85)$ and deuteranopic $(r=-82)$ confusion axes when comparing against non-smokers. As stated, this result does not support the idea of channel selectivity. However, we base our rational on the existence of diffuse processing impairment, which may include magno- and parvocellular pathways.

Nicotine enhances dopamine (DA) release through a balance of activation and desensitization of nicotinic acetylcholine receptors (nAChRs) located mainly in the ventral tegmental area and in the striatum ${ }^{14,28}$. There are also nAChRs and DA receptors on the retina, so it is not hard to understand that the use of nicotine would enhance attentional resources ${ }^{29-31}$. However, we did not observe improvements in color discrimination. So, is there any relationship between smoking and color discrimination? The answer may 

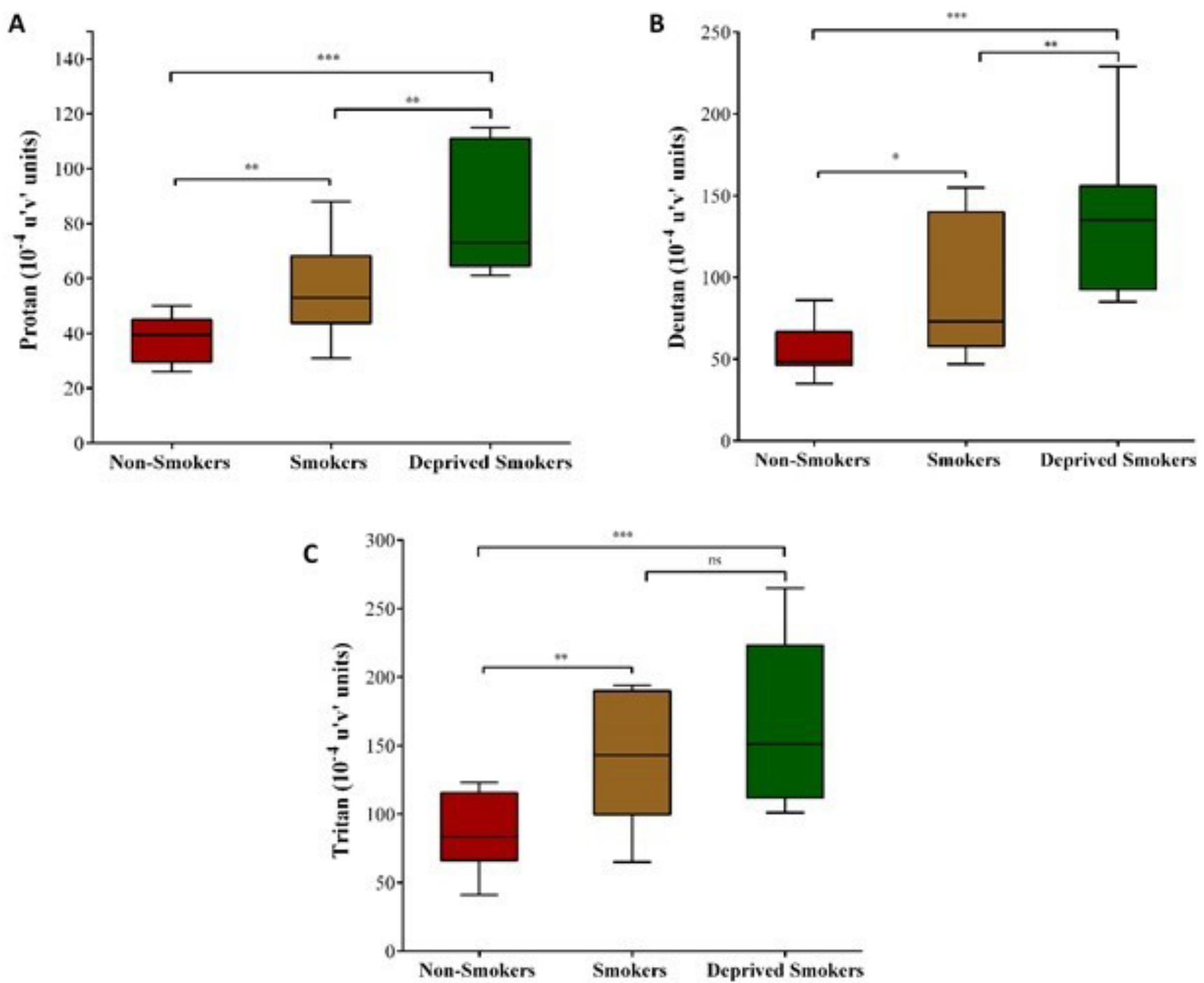

Figure 1. Trivector test: box-and-whiskers plots for protan $(\mathbf{A})$, deutan $(\mathbf{B})$ and tritan $(\mathbf{C})$ confusion lines. Data are presented in $10^{-4} \mathrm{U}^{\prime} v^{\prime}$ units. Each box-and-whiskers plot is based on results for 45 participants. ${ }^{*} P<0.05$; ${ }^{* *} P<0.01$; ${ }^{* *} P<0.001$.

lie in desensitization, which is one of many brain changes caused by addiction $^{32}$. In addition, chronic nicotine exposure leads to nAChRs desensitization through brain upregulation ${ }^{33,34}$. Another property of cigarettes is that the more exposure, the greater the need for it activate the receptors, which changes affinity and response properties of the $\mathrm{nAChRs}{ }^{35,36}$. Whereas nicotine enhancing effects decay and remain unchanged after chronic exposure, this may explain the lower discrimination, but the small similarity, between smokers and non-smokers in some of our data (Figure 1).

Then, why did the deprived smokers group have less discrimination? This can be explained by the withdrawal effect, which induces a hypofunctional effect of DA release ${ }^{37,38}$, reflecting both visual processing $^{39-41}$ and brain reward function ${ }^{42}$. Visual attention plays a role for detection of environmental stimuli ${ }^{43}$.

As stated, impairments observed at color discrimination can occur due to cones saturation, amplification of the signals that reach visual cortex or by the action of nicotine in parvocelular pathway ${ }^{44}$. In agreement with studies, color vision impairments may be related to ventral stream, which processes color ${ }^{45}$. However, our tests used pseudoisochromatic stimuli. Thus, color discrimination may have occurred through dorsal and ventral stream. Maybe it is too soon to conclude anything, but there may be nAChRs in both dorsal and ventral stream. In addition, both streams may suffer from the action of DA hypofunction, affecting directly visual processing $^{38-40,42}$.

Knowing the existence of the expression of nAChRs in bipolar, amacrine and ganglionar cells ${ }^{28,46}$, we suggest that smoking affects visual processing, regardless of deprivation. Although the differences between smokers and non-smokers were small, we could not ignore the existence of many harmful compounds to vision in cigarettes. As noted in others studies, exposure to cigarette smoking ${ }^{47-51}$ and solvents ${ }^{52,53}$ affects vision. Thus, smoking can be harmful even for passive smokers. 
Our limitations need to be considered. We evaluated cigarette smoking as a whole, not the nicotine-only effects ${ }^{49,50}$. Which brings us to the idea of further studies, using nicotine gum and the same paradigm used here. Clearly, further work is needed, but this study highlights the relationship between smoking and color discrimination, involving short, medium and long wavelengths. We conclude that cigarette compounds affect vision more than nicotine separately $y^{5,55}$.

\section{Data availability}

Dataset 1: Patient demographics and Trivector results. Raw data of the subjects biosociodemographic and trivector (protan, deutan and tritan) results. doi, 10.5256/f1000research.10714.d150059 $9^{59}$

\section{Author contributions}

TM: design of the work, data collection and interpretation, and drafting the article. NA: design of the work, data analysis and interpretation, and critical revision of the article. All authors approved the final version to be published.

\section{Competing interests}

No competing interests were disclosed.

Grant information

National Counsel of Technological and Scientific Development (CNPq), Brazil (grant no., 303822/2010-4), CAPES and Federal University of Paraiba funded this paper.

The funders had no role in study design, data collection and analysis, decision to publish, or preparation of the manuscript.

\section{Acknowledgments}

Natalia Leandro de Almeida for helping with data collection and interpretation.
1. Mathers $C D$, Loncar D: Projections of Global Mortality and Burden of Disease from 2002 to 2030 . PLoS Med. 2006; 3(11): e442. PubMed Abstract | Publisher Full Text | Free Full Text

2. WHO: Who report on the global tobacco epidemic, 2013 Reference Source

3. WHO: WHO Report on the Global Tobacco Epidemic, 2015: Raising Taxes on Tobacco. 2015.

Reference Source

4. Bell SL, Taylor RC, Singleton EG, et al:: Smoking after nicotine deprivation enhances cognitive performance and decreases tobacco craving in drug abusers. Nicotine Tob Res. 1999; 1(1): 45-52. PubMed Abstract | Publisher Full Text

5. Harrison EL, Coppola S, McKee SA: Nicotine Deprivation and Trait Impulsivity Affect Smokers' Performance on Cognitive Tasks of Inhibition and Attention. Exp Clin Psychopharmacol. 2009; 17(2): 91-98. PubMed Abstract | Publisher Full Text | Free Full Text

6. Durazzo TC, Meyerhoff DJ, Nixon SJ: Chronic Cigarette Smoking: Implications for Neurocognition and Brain Neurobiology. Int J Environ Res Public Health. 2010; 7(10): 3760-3791.

PubMed Abstract | Publisher Full Text | Free Full Text

7. Thurgood SL, McNeill A, Clark-Carter D, et al.: A Systematic Review of Smoking Cessation Interventions for Adults in Substance Abuse Treatment or Recovery. Nicotine Tob Res. 2016; 18(5): 993-1001.

PubMed Abstract | Publisher Full Text | Free Full Text

8. Wang C, Xu X, Qian W, et al:: Altered human brain anatomy in chronic smokers: a review of magnetic resonance imaging studies. Neurol Sci. 2015; 36(4): 497-504. PubMed Abstract | Publisher Full Text

9. Cornsweet T: Visual Perception. Academic Press; 2012 Reference Source

10. DeValois KK, Webster MA: Color vision. Scholarpedia. 2011; 6(4): 3073. Publisher Full Text

11. DeValois RL, DeValois KK: Spatial Vision. Oxford University Press. 1990. Reference Source

12. Mollon JD, Regan BC: Cambridge Colour Test Handbook. 2000 Reference Source

13. Paramei GV: Color discrimination across four life decades assessed by the Cambridge Colour Test. J Opt Soc Am A Opt Image Sci Vis. 2012; 29(2): A290-297. PubMed Abstract | Publisher Full Text

14. D'Souza MS, Markou A: Neuronal mechanisms underlying development of nicotine dependence: implications for novel smoking-cessation treatments. Addict Sci Clin Pract. 2011; 6(1): 4-16. PubMed Abstract | Free Full Text

15. Regan BC, Reffin JP, Mollon JD: Luminance noise and the rapid determination of discrimination ellipses in colour deficiency. Vision Res. 1994; $34(10)$ 1279-1299.

PubMed Abstract | Publisher Full Text

16. Reffin JP, Astell S, Mollon JD: Trials of a computer-controlled colour vision test that preserves the advantages of pseudoisochromatic plates. In: Drum B, Moreland JD, Serra A, eds. Colour Vision Deficiencies X. Document Ophthalmologica Proceedings Series. Springer: Netherlands; 1991; 69-76. Publisher Full Text

17. Field A: Discovering Statistics Using IBM SPSS Statistics. SAGE; 2013. Reference Source

18. Rosenthal R, Rosnow RL: Effect sizes for experimenting psychologists. Can J Exp Psychol. 2003: 57(3): 221-237. PubMed Abstract | Publisher Full Text

19. Allen AE, Brown TM, Lucas RJ: A distinct contribution of short-wavelengthsensitive cones to light-evoked activity in the mouse pretectal olivary nucleus. J Neurosci. 2011; 31(46): 16833-16843. PubMed Abstract | Publisher Full Text | Free Full Text

20. Delahunt PB, Brainard DH: Control of chromatic adaptation: signals from separate cone classes interact. Vision Res. 2000; 40(21): 2885-2903. PubMed Abstract | Publisher Full Text

21. Purves D, Augustine GJ, Fitzpatrick D, et al.: Cones and Color Vision. Accessed November 9, 2016. 2001 Reference Source

22. Bocanegra BR, Zeelenberg R: Emotional cues enhance the attentional effects on spatial and temporal resolution. Psychon Bull Rev. 2011; 18(6): 1071-1076. PubMed Abstract | Publisher Full Text | Free Full Text

23. Kunchulia M, Pilz KS, Herzog MH: Small effects of smoking on visual spatiotemporal processing. Sci Rep. 2014; 4: 7316. PubMed Abstract | Publisher Full Text | Free Full Text

24. Ahmadi K, Pouretemad HR, Esfandiari J, et al:: Psychophysical Evidence for Impaired Magno, Parvo, and Konio-cellular Pathways in Dyslexic Children. $J$ Ophthalmic Vis Res. 2015; 10(4): 433-440.

PubMed Abstract | Publisher Full Text | Free Full Text

25. Levin ED: Nicotinic Receptors in the Nervous System. CRC Press; 2001 Reference Source

26. Potter AS, Newhouse PA: Acute nicotine improves cognitive deficits in young adults with attention-deficit/hyperactivity disorder. Pharmacol Biochem Behav. 2008; 88(4): 407-417.

PubMed Abstract | Publisher Full Text

27. Quisenaerts C, Morrens M, Hulstijn W, et al.: The nicotinergic receptor as a target for cognitive enhancement in schizophrenia: barking up the wrong tree? Psychopharmacology (Berl). 2014; 231(3): 543-550. PubMed Abstract | Publisher Full Text

28. Quisenaerts C, Morrens M, Hulstijn W, et al:: Acute nicotine improves social decision-making in non-smoking but not in smoking schizophrenia patients. Front Neurosci. 2013; 7: 197. PubMed Abstract | Publisher Full Text | Free Full Text

29. Koob GF, Sanna PP, Bloom FE: Neuroscience of addiction. Neuron. 1998; 21(3): 467-476.

PubMed Abstract | Publisher Full Text

30. Balfour DJ, Munafò MR: The Neuropharmacology of Nicotine Dependence. 
Springer, 2015; 24.

Publisher Full Text

31. Govind AP, Vezina P, Green WN: Nicotine-induced upregulation of nicotinic receptors: underlying mechanisms and relevance to nicotine addiction. Biochem Pharmacol. 2009; 78(7): 756-765.

PubMed Abstract | Publisher Full Text | Free Full Text

32. Besson M, Granon S, Mameli-Engvall M, et al.: Long-term effects of chronic nicotine exposure on brain nicotinic receptors. Proc Natl Acad Sci U S A. 2007; 104(19): 8155-8160.

PubMed Abstract | Publisher Full Text | Free Full Text

33. Vallejo YF, Buisson B, Bertrand D, et al:: Chronic nicotine exposure upregulates nicotinic receptors by a novel mechanism. J Neurosci. 2005; 25(23): 5563-5572. PubMed Abstract | Publisher Full Text | Free Full Text

34. De Biasi M, Dani JA: Reward, addiction, withdrawal to nicotine. Annu Rev Neurosci. 2011; 34: 105-130.

PubMed Abstract | Publisher Full Text | Free Full Text

35. Zhang L, Dong $\mathrm{Y}$, Doyon WM, et al.: Withdrawal from chronic nicotine exposure alters dopamine signaling dynamics in the nucleus accumbens. Biol Psychiatry. 2012; 71(3): 184-191.

PubMed Abstract | Publisher Full Text | Free Full Text

36. Bodis-Wollner I: Visual deficits related to dopamine deficiency in experimental animals and Parkinson's disease patients. Trends Neurosci. 1990; 13(7): 296-302.

PubMed Abstract | Publisher Full Text

37. Jackson CR, Ruan GX, Aseem F, et al.: Retinal dopamine mediates multiple dimensions of light-adapted vision. J Neurosci. 2012; 32(27): 9359-9368. PubMed Abstract | Publisher Full Text | Free Full Text

38. Witkovsky P: Dopamine and retinal function. Doc Ophthalmol. 2004; 108(1): 17-40. PubMed Abstract | Publisher Full Text

39. Wise RA, Rompre PP: Brain dopamine and reward. Annu Rev Psychol. 1989; 40(1): 191-225.

PubMed Abstract | Publisher Full Text

40. Aguirre CG, Madrid J, Leventhal AM: Tobacco withdrawal symptoms mediate motivation to reinstate smoking during abstinence. J Abnorm Psychol. 2015 124(3): 623-634.

PubMed Abstract | Publisher Full Text | Free Full Text

41. Figueiró LR, Bortolon CB, Benchaya MC, et al:: Assessment of changes in nicotine dependence, motivation, and symptoms of anxiety and depression among smokers in the initial process of smoking reduction or cessation: a short-term follow-up study. Trends Psychiatry Psychother. 2013; 35(3): 212-220. PubMed Abstract | Publisher Full Text

42. Pestilli F, Viera G, Carrasco M: How do attention and adaptation affect contrast sensitivity? J Vis. 2007; 7(7): 9.1-912.

PubMed Abstract | Publisher Full Text | Free Full Text

43. Lee TH, Baek J, Lu ZL, et al:: How arousal modulates the visual contrast sensitivity function. Emotion. 2014; 14(5): 978-984. PubMed Abstract | Publisher Full Text | Free Full Text

44. Pollux $\mathrm{PM}$, Hall $\mathrm{S}$, Roebuck $\mathrm{H}$, et al: Event-related potential correlates of the interaction between attention and spatiotemporal context regularity in vision. Neuroscience. 2011; 190: 258-269. PubMed Abstract | Publisher Full Text
45. Butler PD, Zemon V, Schechter I, et al.: Early-stage visual processing and cortical amplification deficits in schizophrenia. Arch Gen Psychiatry. 2005; 62(5): 495-504

PubMed Abstract | Publisher Full Text | Free Full Text

46. Claeys KG, Dupont $P$, Cornette $L$, et al:: Color discrimination involves ventral and dorsal stream visual areas. Cereb Cortex. 2004; 14(7): 803-822. PubMed Abstract | Publisher Full Text

47. Neal MJ, Cunningham JR, Matthews KL: Activation of nicotinic receptors on GABAergic amacrine cells in the rabbit retina indirectly stimulates dopamine release. Vis Neurosci. 2001; 18(1): 55-64. PubMed Abstract | Publisher Full Text

48. Gundogan FC, Durukan AH, Mumcuoglu T, et al:: Acute effects of cigarette smoking on pattern electroretinogram. Doc Ophthalmol. 2006; 113(2): 115-121. PubMed Abstract | Publisher Full Text

49. Varghese SB: The effects of nicotine on the human adult visual pathway and processing. 2013. Reference Source

50. Varghese SB, Reid JC, Hartmann EE, et al.: The Effects of Nicotine on the Human Electroretinogram. Invest Ophthalmol Vis Sci. 2011; 52(13): 9445-9451. PubMed Abstract | Publisher Full Text | Free Full Text

51. Naser NT, Loop M, Than T, et al.: Color Vision: Effects of Nicotine Gum in NonSmokers. Invest Ophthalmol Vis Sci. 2011; 52(14): 4902. Reference Source

52. Oliveira AR: Avaliações psicofísicas cromática e acromática de homens e mulheres expostos a solventes orgânicos. 2015. Reference Source

53. Lacerda EM da CB, Ventura DF, Silveira LC de L: Visual assessment by psychophysical methods of people subjected to occupational exposure to organic solvents. Psicol USP. 2011; 22(1): 117-145. Publisher Full Text

54. Barreto GE, larkov A, Moran VE: Beneficial effects of nicotine, cotinine and its metabolites as potential agents for Parkinson's disease. Front Aging Neurosci. 2015; $6: 340$.

PubMed Abstract | Publisher Full Text | Free Full Text

55. Powledge TM: Nicotine as therapy. PLoS Biol. 2004; 2(11): e404 PubMed Abstract | Publisher Full Text | Free Full Text

56. Mazzone P, Tierney W, Hossain M, et al:: Pathophysiological impact of cigarette smoke exposure on the cerebrovascular system with a focus on the blood-brain barrier: expanding the awareness of smoking toxicity in an underappreciated area. Int J Environ Res Public Health. 2010; 7(12): 4111-4126. PubMed Abstract | Publisher Full Text | Free Full Text

57. Arda H, Mirza GE, Polat OA, et al.: Effects of chronic smoking on color vision in young subjects. Int J Ophthalmol. 2015; 8(1): 77-80. PubMed Abstract | Publisher Full Text | Free Full Text

58. Erb C, Nicaeus T, Adler M, et al.: Colour vision disturbances in chronic smokers. Graefes Arch Clin Exp Ophthalmol. 1999; 237(5): 377-380. PubMed Abstract | Publisher Full Text

59. de Paiva Fernandes TM, dos Santos NA: Dataset 1 in: Comparison of color discrimination in chronic heavy smokers and healthy subjects. F1000Research. 2017 Data Source 


\section{Open Peer Review}

\section{Current Peer Review Status: $\mathrm{X}$ ?}

\section{Version 1}

Reviewer Report 17 March 2017

https://doi.org/10.5256/f1000research.11553.r20562

(C) 2017 da Rosa M. This is an open access peer review report distributed under the terms of the Creative Commons Attribution License, which permits unrestricted use, distribution, and reproduction in any medium, provided the original work is properly cited.

\section{Marine Raquel Diniz da Rosa}

Neuroscience and Behavior Graduate Program , Federal University of Paraíba , João Pessoa, Brazil

The article investigates and compares color discrimination in chronic smokers and healthy individuals. The authors found a lower significant color discrimination in chronic smokers.

However, I believe that in order to clarify the cut-off point of color discrimination, authors should write in Methods the standard of normality used to rate low or high color discrimination. In addition, in the description of the results, for better understanding, the authors should explain better the results (which are below the expected) and then the significance of them.

The results suggest a possible, even small, important change to the color discrimination of smokers which deserves attention and should be better studied. Therefore, I believe that the paper should be accepted for publication with the aforementioned suggestions.

\section{References}

1. Mollon JD, Regan BC: Cambridge Colour Test Handbook. Cambridge Research Systems Ltd.2000.

2. Goulart PRK: A computer-controlled color vision test for children and non-verbal subjects based on the Mollo-Reffin color discrimination test. Doctoral Dissertation, Universidade Federal do Pará. 2008. 75

3. Oliveira A.R: Chromatic and achromatic psychophysical evaluations of men and women exposed to organic solvents. Master Dissertation Universidade Federal da Paraíba. 2015. 75

4. Goulart PR, Bandeira ML, Tsubota D, Oiwa NN, et al.: A computer-controlled color vision test for children based on the Cambridge Colour Test.Vis Neurosci. 25 (3): 445-50 PubMed Abstract I Publisher Full Text

Competing Interests: I am affiliated with The Federal University of Paraiba, where all 3 of the authors, Thiago Monteiro de Paiva Fernandes, Natalia Leandro Almeida and Natanael Antonio dos Santos are also affiliated.

I confirm that I have read this submission and believe that I have an appropriate level of 


\section{expertise to confirm that it is of an acceptable scientific standard, however I have significant reservations, as outlined above.}

\section{Author Response 24 Mar 2017}

Thiago P Fernandes, Federal University of Paraiba, Brazil

Dear Marine,

First of all, many thanks for the reading and suggestions for our manuscript.

We will try to answer your questions below:

However, I believe that in order to clarify the cut-off point of color discrimination, authors should write in Methods the standard of normality used to rate low or high color discrimination.

We appreciate the suggestion. These changes were made. We stand by calculating the average of the control group of all studies using Trivector in Brazil and using the normative data for age groups used by Paramei et al. ${ }^{1}$

In addition, in the description of the results, for better understanding, the authors should explain better the results (which are below the expected) and then the significance of them. We appreciate the suggestion. Although the description of Trivector's results is quite directive (for details, see ${ }^{2-5}$ ), we agreed that the way the results were presented was below expectations. These changes were made.

The results suggest a possible, even small, important change to the color discrimination of smokers which deserves attention and should be better studied.

In agreement. Based on this suggestion, we added a few paragraphs on the importance of the present study, see Introduction and Discussion.

\section{References:}

1. Paramei GV. Color discrimination across four life decades assessed by the Cambridge Colour Test. J Opt Soc Am A Opt Image Sci Vis. 2012;29(2):A290-297.

2. Lacerda EM da CB, Ventura DF, Silveira LC de L: Visual assessment by psychophysical methods of people subjected to occupational exposure to organic solvents. Psicol USP. 2011;22(1):117-145. 10.1590/S0103-65642011005000011

3. Oliveira AR: Avaliações psicofísicas cromática e acromática de homens e mulheres expostos a solventes orgânicos.2015. Reference Source

4. Goulart PRK, Bandeira ML, Tsubota D, Oiwa NN, Costa MF, Ventura DF. A computercontrolled color vision test for children based on the Cambridge Colour Test. Vis Neurosci. 2008;25(3):445-450. doi:10.1017/S0952523808080589.

5. Costa MF, Oliveira AGF, Feitosa-Santana C, Zatz M, Ventura DF. Red-Green Color Vision Impairment in Duchenne Muscular Dystrophy. Am J Hum Genet. 2007;80(6):1064-1075

Competing Interests: None. 
Reviewer Report 10 March 2017

https://doi.org/10.5256/f1000research.11553.r20559

(C) 2017 Maehara G. This is an open access peer review report distributed under the terms of the Creative Commons Attribution License, which permits unrestricted use, distribution, and reproduction in any medium, provided the original work is properly cited.

\section{Goro Maehara}

Department of Human Sciences, Kanagawa University, Yokohama, Japan

The authors measured color discrimination thresholds in chronic smokers and non-smokers using the Cambridge Color Test. The color discrimination thresholds were significantly higher for chronic smokers than non-smokers. Although their methods were scientifically sound, the thresholds for chronic smokers were not high enough to conclude that smoking impairs their color discrimination abilities.

Major concern

1. The thresholds for chronic smokers

According to Mollon \& Regan (2000) 1 , "normal limits for performance for first examination on the basic "Trivector" test are 100 (protan), 100 (deutan) and 150 (tritan)." The threshold medians for chronic smokers were lower than those values, except for the deutan threshold median for deprived smokers.

Although there were statistically significant difference between chronic smokers and nonsmokers, the thresholds for non-smokers were very low (about 40, 50, and 80 in $10^{-4} u^{\prime} v^{\prime}$ units for protan, deutan, and tritan, respectively). In addition, the differences in thresholds (about 60) make little change in color appearance.

Taken together, it seems difficult to conclude that smoking impairs color discrimination abilities.

Minor concern

\section{Equation 1}

I am not sure why Weber contrast (equation 1) needs to be explained in the Methods section. The authors should state clearly how they used the equation in their experiment.

\section{Results}

The authors just listed the statistical results in the Results section. I suggest describing the results in the more detailed way (ex. thresholds were higher for smokers than non-smokers, $U=132, P=$ $0.002, r=-.61)$.

\section{3rd paragraph in the Discussion section}

The authors stated that "smokers were more sensitive to protanopic and deutanopic confusion axes." This sentence is confusing. Which does this sentence mean, "more sensitive than nonsmokers" or "more sensitive than to tritanopic axes"? 


\section{References \\ 1. Mollon JD, Regan BC: Cambridge Colour Test Handbook (version 1.1). Cambridge Research Systems Ltd.2000. Reference Source}

Competing Interests: No competing interests were disclosed.

\section{I confirm that I have read this submission and believe that I have an appropriate level of expertise to state that I do not consider it to be of an acceptable scientific standard, for reasons outlined above.}

Author Response 10 Mar 2017

Thiago P Fernandes, Federal University of Paraiba, Brazil

Dear Goro Maehara,

We respectfully thank you for the reading and responding to our manuscript.

If I may contest your decision of this manuscript, we respectfully do not agree that it can not be accepted as an acceptable scientific standard. We believe that the data contribute in terms of scientific validity, and because we know that there are few studies on color vision in chronic smoking (and abstinence).

We will try to answer your questions below:

"Although their methods were scientifically sound, the thresholds for chronic smokers were not high enough to conclude that smoking impairs their color discrimination abilities."

Although we did not observe large differences between the thresholds of the control group and the group of smokers, we agree with Lakens (2013) and Field (2013) noting that the statistically significant differences are consonant with the related effect sizes which fluctuated between mid-to-high values ( $r$ values between .50 and .61 ; chronic smokers $x$ controls). Moreover, when comparing the group of smokers with deprived smokers, we observed that these differences were not so large ( $r$ values reaching .50$)$. We do not know if the smoking habit, cigarette compounds or smoking per se, are responsible for the decrease in color discrimination.

But there was a loss of color discrimination, suggesting the idea that visual color processing may be diffusely impaired in smokers (Besson et al., 2007; Vallejo, Buisson, Bertrand, \& Green, 2005; Zhang, Dong, Doyon, \& Dani, 2012). We base this hypothesis on the fact that the many cigarette compounds, including organic solvents in the cigarette smoke, impairs color processing per se.

\section{Major Concern}

'The threshold medians for chronic smokers were lower than those values, except for the deutan threshold median for deprived smokers. Although there were statistically significant difference between chronic smokers and non-smokers, the thresholds for non- 
smokers were very low (about 40,50, and 80 in 10-4 u' v' units for protan, deutan, and tritan, respectively). In addition, the differences in thresholds (about 60) make little change in color appearance. Taken together, it seems difficult to conclude that smoking impairs color discrimination abilities.'

Many thanks for the review.

Based on our expertise in the use of Cambridge Colour Test: the minor the threshold, better discrimination. If a group (in this case, smokers group) has a higher threshold, this means that they needed more chromatic contrast to detect the stimuli. Thus, higher thresholds means lower discriminiation along confusion axes (Hasrod \& Rubin, 2015).

After the publication of Mollon and Reffin's about the CCT (2000), several studies using Trivector have been published. Including preliminary norms for the use of CCT (Ventura et al., 2003), which was considered by the creators of the CCT on the software website (http://www.crsltd.com/tools-for-vision-science/measuring-visual-functions/cambridgecolour-test/)

We re-checked our Trivector data and compared to several studies and we observed that we're with similar values for control groups. If another group (such smokers or deprived smokers) had higher thresholds, it means that they differ from the standard values and are likely to have color vision impairments.

As shown in the other studies, values for control subjects have fluctuated precisely in the values that we obtained in our data (Costa et al., 2007; Goulart et al., 2008; Paramei, 2012, 2014; Ventura et al., 2002).

Thus, the raising of the threshold of smokers is possibly connected with smoking conditions, since we've matched all possibly intervenient variables.

Taken together, we can not ignore that, although not as large, the differences were significant in this sample. Based on previous studies, even though there are small differences, they need to be punctuated, since we agree that this is an important area that requires further research.

\section{Minor concern}

1. Equation 1; I am not sure why Weber contrast (equation 1) needs to be explained in the Methods section. The authors should state clearly how they used the equation in their experiment.

Ops! Many thanks! Since CCT already uses this default setting, we strongly agreed with your review. These changes will be in the second version of the manuscript (we will remove it).

2. Results; The authors just listed the statistical results in the Results section. I suggest describing the results in the more detailed way (ex. thresholds were higher for smokers than non-smokers, $U=132, P=0.002, r=-.61$ ). 
Many thanks again. We believe that the way you suggested will facilitate the reader's understanding and will enhance the scientific level of our writing. We fixed it. They will be more descriptive in the next version

3. 3rd paragraph in the Discussion section; The authors stated that "smokers were more sensitive to protanopic and deutanopic confusion axes." This sentence is confusing. Which does this sentence mean, "more sensitive than non-smokers" or "more sensitive than to tritanopic axes"?

We appreciate the suggestion and agree that the use of two forms of explanation may actually confuse the reader. We will correct this.

However, when we mention that the smoking group was more sensitive to the protanopic or deutanopic axes, we simply mean that they made more errors than the control group, for example. That is, they needed more chromatic contrast (they were more sensitive) than the comparison group. The confusion axes refer to the red (protanopic), green (deutanopic) and blue (tritanopic) axes. Thus, if any group was more sensitive to the red confusion axis, forr example, it means that they possibly had impairments in the processing of this wavelength.

In this way, based on the apointments above, the 'not approved' status is honestly inconsistent with the content of the work. We ask you to reconsider your decision and we are grateful for the comment, reading, and review of the manuscript.

\section{References}

1. Lakens D. Calculating and reporting effect sizes to facilitate cumulative science: a practical primer for t-tests and ANOVAs. Front. Psychol. [Internet]. 2013 [cited 2017 Mar 10];4. Available from: http://journal.frontiersin.org/article/10.3389/fpsyg.2013.00863/abstract

\section{Field A. Discovering Statistics Using IBM SPSS Statistics. SAGE; 2013.}

3. Besson M, Granon S, Mameli-Engvall M, Cloëz-Tayarani I, Maubourguet N, Cormier A, et al. Long-term effects of chronic nicotine exposure on brain nicotinic receptors. Proc. Natl. Acad. Sci. 2007;104:8155-60.

4. Vallejo YF, Buisson B, Bertrand D, Green WN. Chronic Nicotine Exposure Upregulates Nicotinic Receptors by a Novel Mechanism. J. Neurosci. Off. J. Soc. Neurosci. 2005;25:5563-72.

5. Zhang L, Dong Y, Doyon WM, Dani JA. Withdrawal from Chronic Nicotine Exposure Alters Dopamine Signaling Dynamics in the Nucleus Accumbens. Biol. Psychiatry. 2012;71:184-91.

6. Mollon JD, Regan BC. Cambridge Colour Test Handbook [Internet]. 2000. Available from: https://sites.oxy.edu/clint/physio/article/CAMBRIDGECOLOURTESTHandbook.pdf

7. Ventura DF, Silveira LC de L, Rodrigues A, Costa MF. Preliminary Norms for the Cambridge Colour Test. 2003;331-9. 
8. Costa MF, Oliveira AGF, Feitosa-Santana C, Zatz M, Ventura DF. Red-Green Color Vision Impairment in Duchenne Muscular Dystrophy. Am. J. Hum. Genet. 2007;80:1064-75.

9. Feitosa-Santana C, Barboni MTS, Oiwa NN, Paramei GV, Simões ALAC, Da Costa MF, et al. Irreversible color vision losses in patients with chronic mercury vapor intoxication. Vis. Neurosci. 2008;25:487-91.

10. Goulart PRK, Bandeira ML, Tsubota D, Oiwa NN, Costa MF, Ventura DF. A computercontrolled color vision test for children based on the Cambridge Colour Test. Vis. Neurosci. 2008;25:445-50.

11. Paramei GV. Color discrimination across four life decades assessed by the Cambridge Colour Test. J. Opt. Soc. Am. A Opt. Image Sci. Vis. 2012;29:A290-297.

12. Paramei GV, Oakley B. Variation of color discrimination across the life span. JOSA A. 2014;31:A375-84.

13. Pelli DG, Bex P. Measuring contrast sensitivity. Vision Res. 2013;90:10-4.

14. Hogg RE, Chakravarthy U. Visual function and dysfunction in early and late age-related maculopathy. Prog. Retin. Eye Res. 2006;25:249-76.

15. DeValois KK, Webster MA. Color vision. Scholarpedia. 2011;6:3073.

Competing Interests: No competing interests were disclosed.

Reviewer Response 19 Mar 2017

Goro Maehara, Kanagawa University, Yokohama, Japan

Dear Thiago,

I am happy to review the revised manuscript.

Please make it clear that the thresholds of normal observers were comparable with those reported by previous studies using the Cambridge color test.

According to Thornton, Edwards, Mitchell, Harrison, Buchan \& Kelly (2005), there is a strong association between current smoking and age-related macular degeneration. This line of studies could strengthen your paper.

Regards,

Goro 
Competing Interests: No competing interests were disclosed.

\section{Author Response 24 Mar 2017}

Thiago P Fernandes, Federal University of Paraiba, Brazil

Dear Goro,

Many thanks for the quick answer.

Based on your suggestions, substantial changes were made.

We inserted a subsection in the methods where we explained the cutoff points (where the results would be normal and where the discrimination losses would be).

In addition, we better describe the results section, making it clear to the reader that the higher the threshold, the lower the color discrimination. Also, based on your last suggestion, we added a few paragraphs about the relationship between the harmful cigarette compounds and the damage they cause to the retina, and consequently, visual processing.

I hope we have answered the suggestions. Again, we ask you to reconsider your decision about the status of our work.

Best regards,

Competing Interests: None.

The benefits of publishing with F1000Research:

- Your article is published within days, with no editorial bias

- You can publish traditional articles, null/negative results, case reports, data notes and more

- The peer review process is transparent and collaborative

- Your article is indexed in PubMed after passing peer review

- Dedicated customer support at every stage

For pre-submission enquiries, contact research@f1000.com 